\title{
緩傾斜護岸の越波特性に関する実験的研究 EXPERIMENTAL STUDIES ON THE CHARACTERISTICS OF WAVE OVERTOPPING ON GENTLE SLOPE-TYPE SEAWALLS
}

\author{
玉田 崇 1 - 手塚崇雄 1 ・井上雅夫2 \\ Takashi TAMADA, Takao TEZUKA and Masao INOUE \\ 1学生員 関西大学大学院 工学研究科土木工学専攻（T564-8680 大阪府吹田市山手町3-3-35) \\ ${ }^{2}$ 正会員 工博 関西大学教授 工学部土木工学科（テ564-8680 大阪府吹田市山手町3-3-35）
}

\begin{abstract}
The purpose of this study is to clarify the characteristics of wave overtopping on gentle slope-type seawall. Therefore, experiments on wave overtopping by irregular waves were carried out for gentle slope-type seawalls. Using the results, effects of the ratio of the water depth to the wave height, the relative crown height of the seawall, the sea bottom slope and the slope gradient of the seawall on the wave overtopping rate of gentle slope-type seawalls were discussed. And, an optimum combination between slope gradient of the seawalls and sea bottom slope was examined from the wave overtopping prevention of view. In addition, frequency of appearance distribution of wave overtopping rate was also investigated.
\end{abstract}

Key Words: Wave overtopping, wave overtopping rate, gentle slope-type seawall

\section{1. 緒 言}

近年，我が国における海岸整備に関しては，親水 性が要求されることから, 天端高をできるだけ低く 抑えた緩傾斜護岸の建設事例が増加傾向にある。こ の緩傾斜護岸における越波現象は, 水理現象のなか でもきわめて複雑なものであり，それに関わる要因 のわずかな違いによって, 越波量などが大幅に変化 する微妙な現象でもある. 従来, こうした問題に関 しては, 若干の実験的な検討 ${ }^{1), 2)}$ は行われているも のの，その全容が明らかにされているわけではない. また最近, 護岸の緩傾斜化については, 護岸前面に わずかに残されていた自然海浜の大半をコンクリー トで覆うため, 人為的な海岸侵食を助長するなどの 問題点も指摘されている゙?.

したがって, この研究では, 緩傾斜護岸の越波現 象に関わる無次元量を種々変化させた一連の越波実 験を行い, 緩傾斜護岸の越波特性に及ぼす諸要素の 影響を検討し，その系統的な傾向の把握を試みた。 また, 護岸断面を小さくしても, 優れた越波防止機 能が発揮できる最適な護岸ののり面勾配と海底勾配
との組み合わせを調べるとともに，越波特性の時間 的変動についても検討を加えた.

\section{2. 実験概要}

この研究では, 大別して二種類の実験を行った. 一つは，緩傾斜護岸の越波特性を調べるもので，い ま一つは, 越波防止の観点から, 緩傾斜護岸ののり 面勾配と海底勾配の最適な組み合わせを見出そうと するものである。

まず，越波特性に関する実験では，2次元不規則 波造波水槽（長さ $25.0 \mathrm{~m}$, 幅 $0.5 \mathrm{~m}$, 深さ $0.6 \mathrm{~m}$ ) 内に 設けた傾斜海浜上に緩傾斜護岸を設置して, 越波現 象に関係するのり先水深・波高比 $\mathrm{h} / \mathrm{H}_{0}$, 相対護岸天 端高 $\mathrm{h}_{\mathrm{c}} / \mathrm{H}_{0}$, 波形勾配 $\mathrm{H}_{0} / \mathrm{L}_{0}$ などの無次元量を種々変 化させて, 反射率 $\mathrm{K}_{\mathrm{r}}$, 越波率 $\mathrm{r}_{0}$ および越波流量 $\mathrm{q}$ の測 定を行った．図ー1には，これらの記号の定義を示 した。実験に用いた入射波は，有義波周期 Tが $1.0 \mathrm{~s}$ のBretschneider ・光易型スペクトルを有する不規則 波である. 表一1には, 基本的な実験条件を示した が，一部の実験では， $\mathrm{H}_{0} / \mathrm{L}_{0}$ を0.02および $0.04, \mathrm{~h}_{\mathrm{c}} / \mathrm{H}_{0}$ 


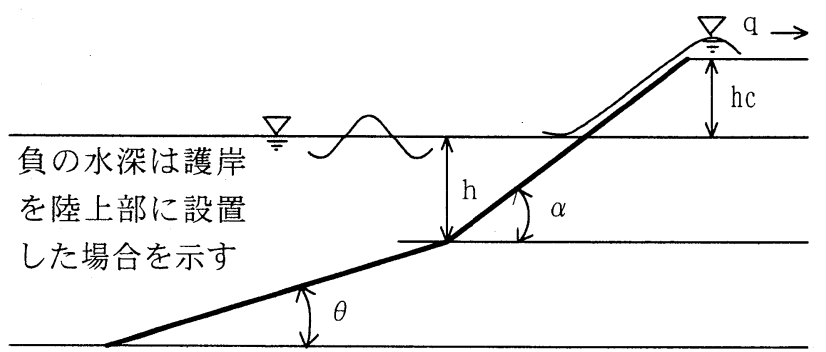

図-1 記号の定義

表 -1 実験条件

\begin{tabular}{|c|c|c|}
\hline 沖波皮形勾配 & $\mathrm{H}_{0} / \mathrm{L}_{0}$ & $0.017,0.036$ \\
\hline のり先水深·波高比 & $\mathrm{h} / \mathrm{H}_{0}$ & $-0.27,0,0.18,0.36,0.71$ \\
\hline 相盿護岸天端高 & $h_{0} / H_{0}$ & $0.5,0.75,1.0,1.25,1.5$ \\
\hline 海底公配 & $\cot \theta$ & 10,30 \\
\hline 護岗のり面公配 & $\cot \alpha$ & $3,5,7$ \\
\hline
\end{tabular}

を0.24および0.48とした。

また，海底勾配とのり面勾配の組み合わせを変化 させた実験では，それらをいずれも7，10および20 割の3種類に変化させ，それぞれを組み合打せた合 計9ケースについては，1波ごとの越波流量も計測し， 代表波法と同じ定義による代表越波量比を計算した。 さらに，1波ごとの越波流量の出現頻度分布から， その超過発生確率についても検討した。

\section{3. 越波特性に及ぼす諸要素の影響}

\section{（1）のり先水深・波高比 $h / \mathrm{H}_{0}$ の影響}

図一 2 には, 反射率 $\mathrm{K}_{\mathrm{r}}$ および越波率 $\mathrm{r}_{0}$ とのり先水 深・波高比 $\mathrm{h} / \mathrm{H}_{0}$ との関係を示した。図一2(a)および (b)は，相対護岸天端高 $\mathrm{h}_{\mathrm{c}} / \mathrm{H}_{0}$ がそれぞれ0.5および 1.5 の場合のものである.

図－2(a)によると, いずれの護岸の $\mathrm{K}_{\mathrm{r}}$ も, $\mathrm{h} / \mathrm{H}_{0}$ が 増大するにつれて，若干増大する傾向がみられる。 特に，この傾向は3割勾配護岸のものに顕著にみら れ, $\mathrm{h} / \mathrm{H}_{0}$ が 0.3 程度よりも大きくなると, $\mathrm{K}_{\mathrm{r}}$ の最小值 よりも場合によっては約 $30 \%$ も増大する。すなわち， のり面勾配が急なほど， $\mathrm{K}_{\mathrm{r}}$ に及ぼす $\mathrm{h} / \mathrm{H}_{0}$ の影響は大 きい。，一方， $\mathrm{r}_{0}$ は，いずれの護岸においても， $\mathrm{h} / \mathrm{H}_{0}$ がー0.27〜0の範囲では急激に増大し， $\mathrm{h} / \mathrm{H}_{0}$ が約 0.3 よりも大きくなると, 緩やかな増加傾向に変化する.

図一2(b)においても， $\mathrm{K}_{\mathrm{r}}$ には, 図一2(a)と同様の傾 向がみられる。一方，3割および5割勾配護岸の $\mathrm{r}_{0}$ は, $\mathrm{h} / \mathrm{H}_{0}$ が増大するにつれて増加し, $\mathrm{h} / \mathrm{H}_{0}$ の影響が顕著 であるのに対して，7割勾配護岸では，その影響は あまりみられない. なお, 豊島 ${ }^{4)} は$, 波の打上げ高 についても同様な傾向があることを指摘している.

図－3には, 無次元越波流量 $\mathrm{q} / \sqrt{2 \mathrm{gH}_{0}}$ および護岸 のり先部における進行波としての有義波高と換算沖
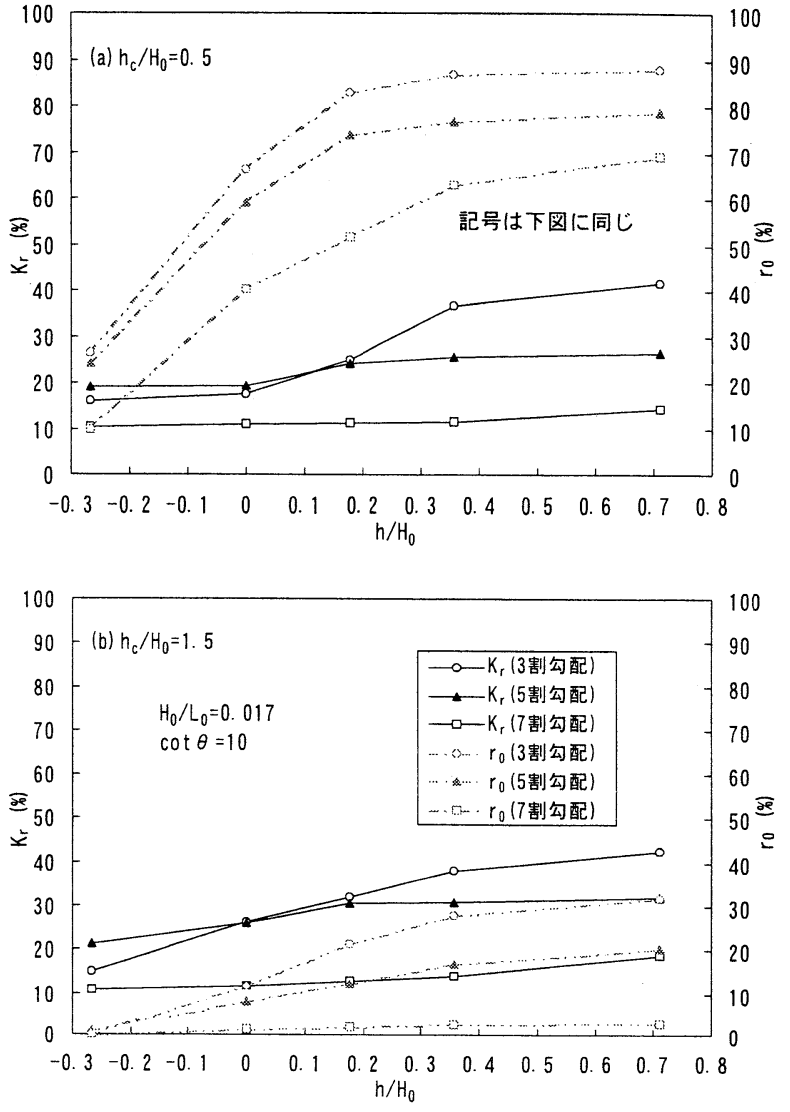

図－2 反射率および越波率とのり先水深・波高比との 関係
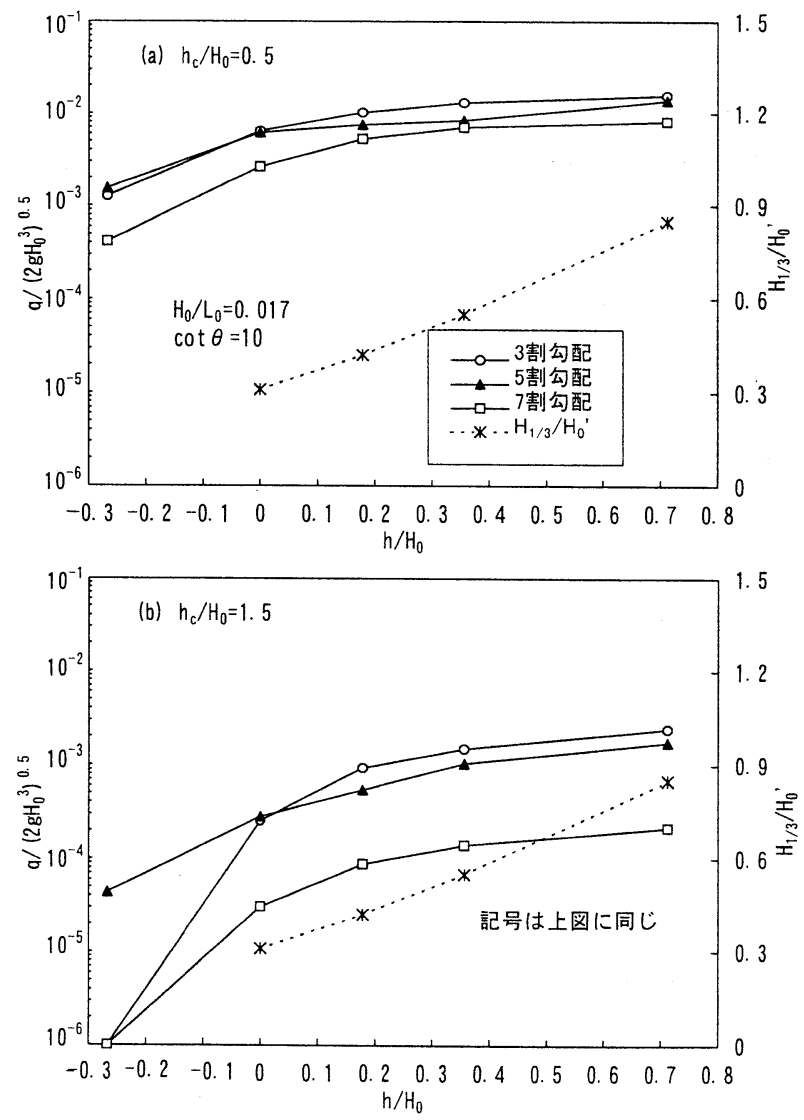

図 -3 無次元越波流量とのり先水深・波高比との関係 
波波高の比 $\mathrm{H}_{1 / 3} / \mathrm{H}_{0}$ ' とのり先水深・波高比 $\mathrm{h} / \mathrm{H}_{0}$ との関 係を図ー2 と同様に示した。この $\mathrm{H}_{1 / 3} / \mathrm{H}_{0}{ }^{\prime}$ の值は合 田占によるものである.

図一3(a)によると，いずれの護岸においても， $\mathrm{h} / \mathrm{H}_{0}$ が増大するにつれて, $\mathrm{q} / \sqrt{2 \mathrm{gH}_{0}}$ も増大する. この原因は，のり先水深が大きくなると，砕波変形 に伴う波高減衰の影響があまりみられないまま, 波 高の大きな波が護岸を越波するためと考えられる.

このことは, 合田 ${ }^{6}$ による既往の研究結果と概子一 致しており， $\mathrm{H}_{1 / 3} / \mathrm{H}_{0}{ }^{\prime}$ も同様に増大していることがわ かる.

図ー3(b)においても，図-3(a) と同様の傾向がみら れる. なお，この傾向は図一2で示した $\mathrm{r}_{0}$ と同様であ り, 越波率と越波流量との間には相関のあることが

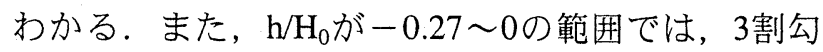
配護岸の $\mathrm{q} / \sqrt{2 \mathrm{gH}_{0}}$ は, 5 割勾配護岸のものよりも小 さくなる．したがって，のり面勾配が急な3割勾配 護岸でも，それを陸上部に設置した場合に限っては, その越波防止効果が期待できる。このように，越波 特性に及ぼすのり先水深の影響は, 護岸ののり面勾 配によっても異なり，このことは, 緩傾斜護岸の計 画上, 特に注意しなければならない。

\section{（2）相対護岸天端高 $h_{c} / H_{0}$ の影響}

図ー4には, 反射率 $\mathrm{K}_{\mathrm{r}}$ および越波率 $\mathrm{r}_{0}$ と相対護岸天 端高 $\mathrm{h}_{\mathrm{d}} / \mathrm{H}_{0}$ との関倸を示した。図一4(a)および(b)は, のり先水深・波高比h $/ \mathrm{H}_{0}$ がそれぞれ0および0.71の場 合のものである.

図一4(a)によると, いずれの護岸の $\mathrm{K}_{\mathrm{r}}$ も, $\mathrm{h}_{\mathrm{c}} / \mathrm{H}_{0}$ が 増大しても, 若干の変動がみられるものの, その值 はほぼ一定であり, 実験值の変動範囲内にある.す なわち， $\mathrm{K}_{\mathrm{r}}$ には， $\mathrm{h}_{\mathrm{c}} / \mathrm{H}_{0}$ の影響はほとんどないものと 考えられる，一方，いずれの護岸の $\mathrm{r}_{0} も ， \mathrm{~h}_{\mathrm{c}} / \mathrm{H}_{0}$ が大 きくなると急激に減少し, $\mathrm{h}_{\mathrm{c}} / \mathrm{H}_{0}$ の影響が顕著に現れ ている.

図ー4(b)においても， $\mathrm{K}_{\mathrm{r}}$ に及ぼす $\mathrm{h}_{\mathrm{c}} / \mathrm{H}_{0}$ の影響はほ とんどみられず，ほぼ一定值を示すが，その值は図 -4(a)のものに比べて大きい。特に，3割勾配護岸の 場合には，約40\%にもなる。したがって，このよう な場合には, 緩傾斜護岸であっても反射波の影響を 無視することはできない.

図一 5 には, 無次元越波流量 $\mathrm{q} / \sqrt{2 \mathrm{gH}_{0}{ }^{3}}$ と相対護岸 天端高 $\mathrm{h}_{\mathrm{c}} / \mathrm{H}_{0}$ との関係を図ー4 と同様に示した.

図一5(a)によると，いずれの護岸においても，図 一 4 に示した $\mathrm{r}_{0}$ と同様に, $\mathrm{q} / \sqrt{2 \mathrm{gH}_{0}}$ に及ぼす $\mathrm{h}_{\mathrm{c}} / \mathrm{H}_{0}$ の 影響がみられ, $\mathrm{h}_{\mathrm{c}} / \mathrm{H}_{0}$ の増大に伴い, $\mathrm{q} / \sqrt{2 \mathrm{gH}_{0}}{ }^{3}$ は減 少する。特に, 7割勾配護岸において, その影響が 顕著である。このことから, 越波防止対策としての 護岸の嵩上げは，のり面勾配が紱い之効果的である が, 緩傾斜護岸の天端を嵩上げすることは，その長 所を衰失しかねない.

困一5(b)においても，図-5(a) と同様の傾向がみら
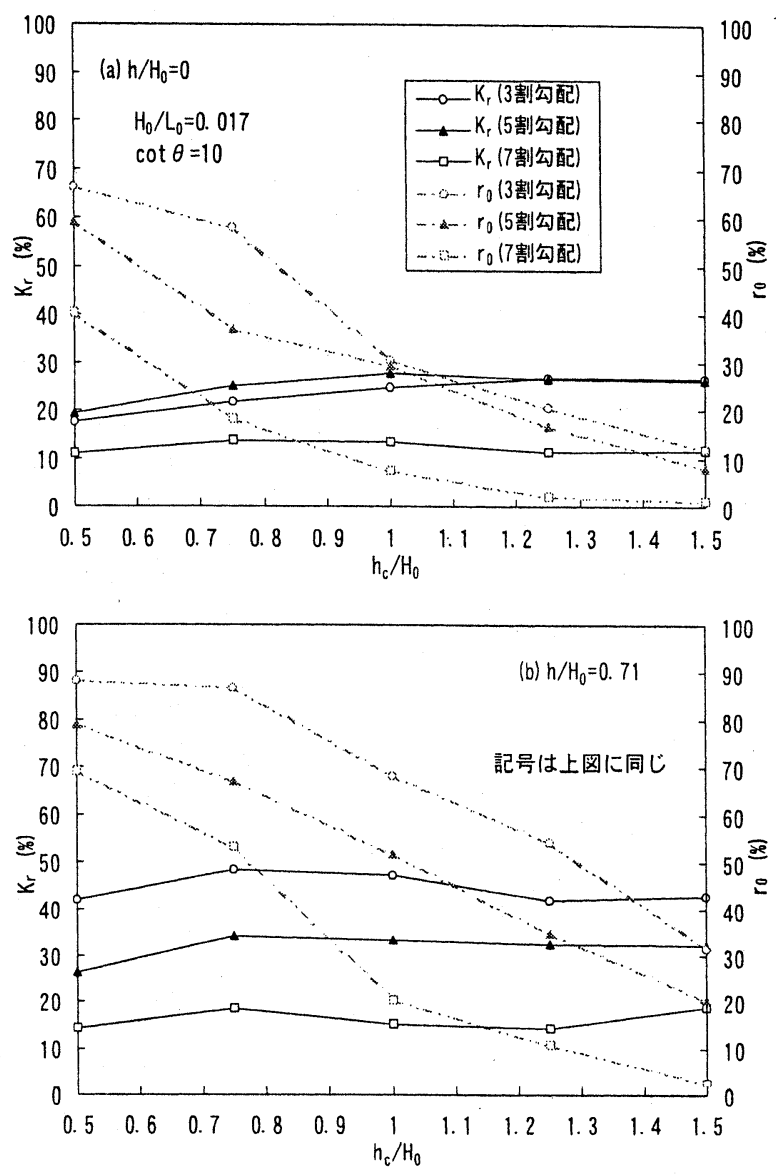

図-4 反射率および越波率と相対護岸天端高との関係
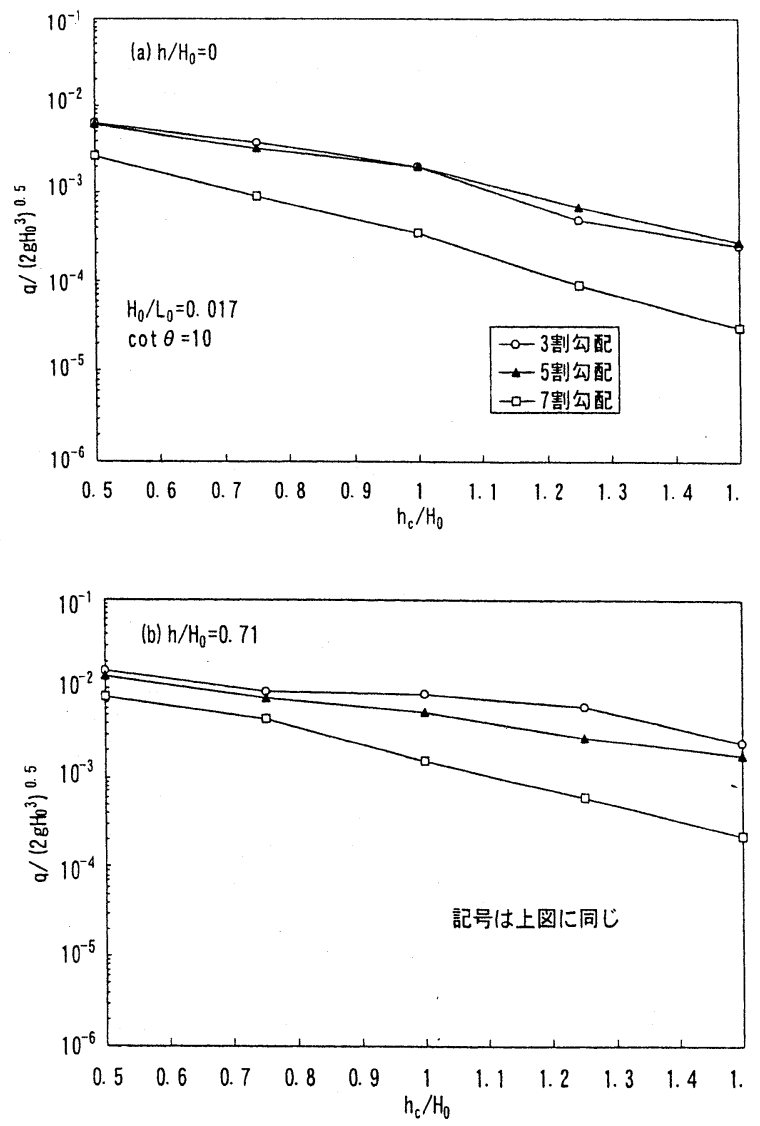

図-5 無次元越波流量と相対護岸天端高との関係 
れる.また，いずれの相対護岸天端高においても， のり面勾配が緩いものほど越波流量は小さい。この ように, のり面勾配が緩やかになると, 緩傾斜護岸 の越波流量は減少する。 その要因は, のり面勾配が 緩い場合には, 急勾配のものに比べて, のり面の長 さが長くなり，砕波した波が護岸上を遡上する際に， その波のもつエネルギーが失われるためである.

\section{（3）海底勾配の影響}

図一6には, 反射率 $\mathrm{K}_{\mathrm{r}}$ および越波率 $\mathrm{r}_{0}$ と海底勾配 $\cot \theta$ との関係を示した. 図一6(a) は波形勾配 $\mathrm{H}_{0} / \mathrm{L}_{0}$ が 0.017 で相対護岸天端高 $\mathrm{h}_{c} / \mathrm{H}_{0}$ が 0.5 の場合, 図一6(b)は 波形勾配 $\mathrm{H}_{0} / \mathrm{L}_{0}$ が 0.02 で相対護岸天端高 $\mathrm{h}_{\mathrm{c}} / \mathrm{H}_{0}$ が 0.48 の 場合のものである.

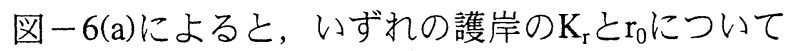
も, 海底勾配が緩くなると減少する傾向がみられる。 特に, $\mathrm{r}_{0}$ にその傾向が顕著にみられる.

図一6(b)においても，7割勾配護岸や10割勾配護岸 については，図一 かし， 20 割勾配護岸の $\mathrm{K}_{\mathrm{r}}$ や $\mathrm{r}_{0}$ の変動傾向は他のもの とは異なる。特に $\mathrm{K}_{\mathrm{r}}$ は, 海底勾配が $1 / 7$ の場合に, のり面勾配が急な護岸のものよりも大きいが，これ については，20割勾配護岸からの戻り流れが他の護 岸の場合とは異なっていることが考えられる.
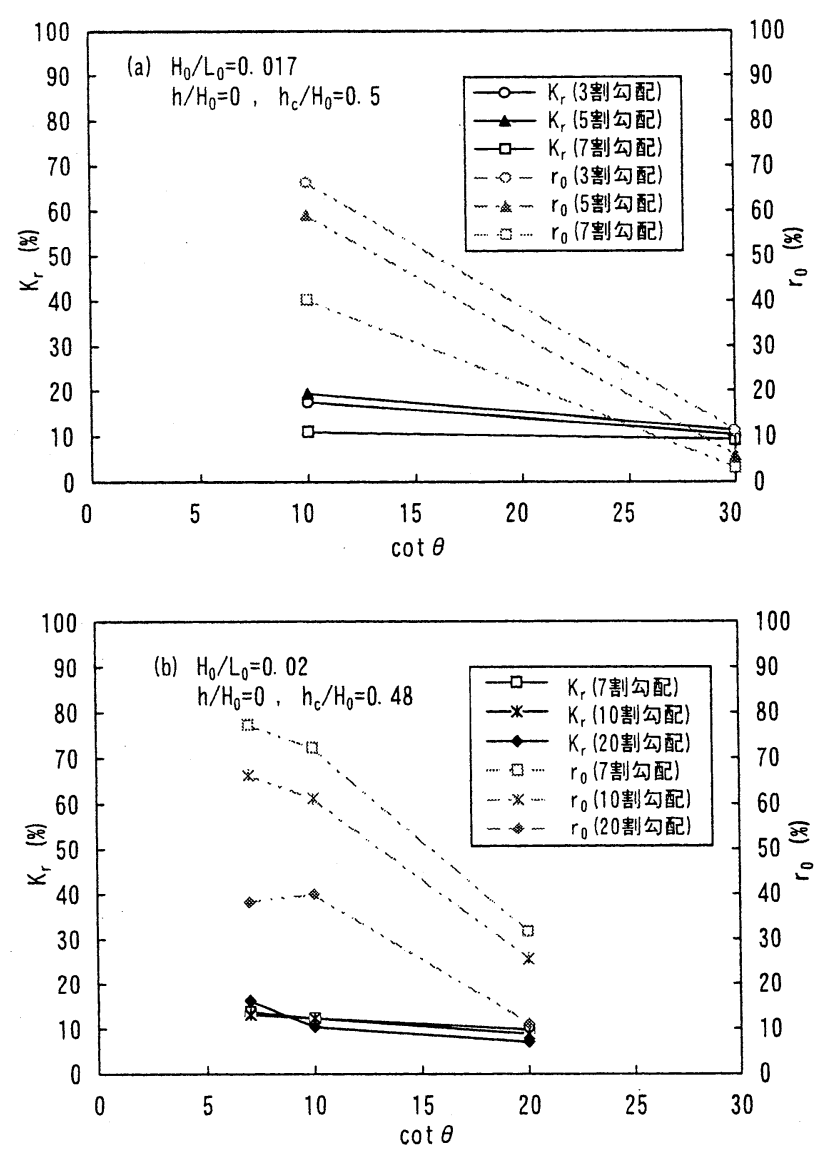

図-6 反射率および越波率と海底勾配との関係
図一7には，無次元越波流量 $\mathrm{q} / \sqrt{2 \mathrm{gH}_{0}}$ および前述 した $\mathrm{H}_{1 / 3} / \mathrm{H}_{0}$ ' と海底勾配 $\cot \theta$ との関係を図一6 同様 に示した.

図一7(a)によると, 海底勾配, のり面勾配のいず れも急なものほど, $\mathrm{q} / \sqrt{2 \mathrm{gH}_{0}}$ は大きい。これは, 砕波帯が岸側に出現することが多くなり, 波のエネ ルギーがほとんど減衰されないまま, 短いのり面を 這い上がるように越波するためである.

一方，図一7(b)においては，.7割および20割勾配護 岸の $\mathrm{q} / \sqrt{2 \mathrm{~g} \mathrm{H}_{0}}{ }^{3}$ は, 海底勾配が緩くなるにつれて減 少するのに対して，10割勾配護岸のものは, 海底勾 配が $1 / 10$ の場合に最大値を示す。このように, 海底 勾配とのり面勾配の組み合わせによっては，のり面 勾配が緩いにもかかわらず，それが急なものよりも 越波流量が大きくなる場合がある．換言すれば，の り面勾配が急な護岸であっても, 海底勾配を緩やか にすると，その越波防止機能を向上させることがで きる.
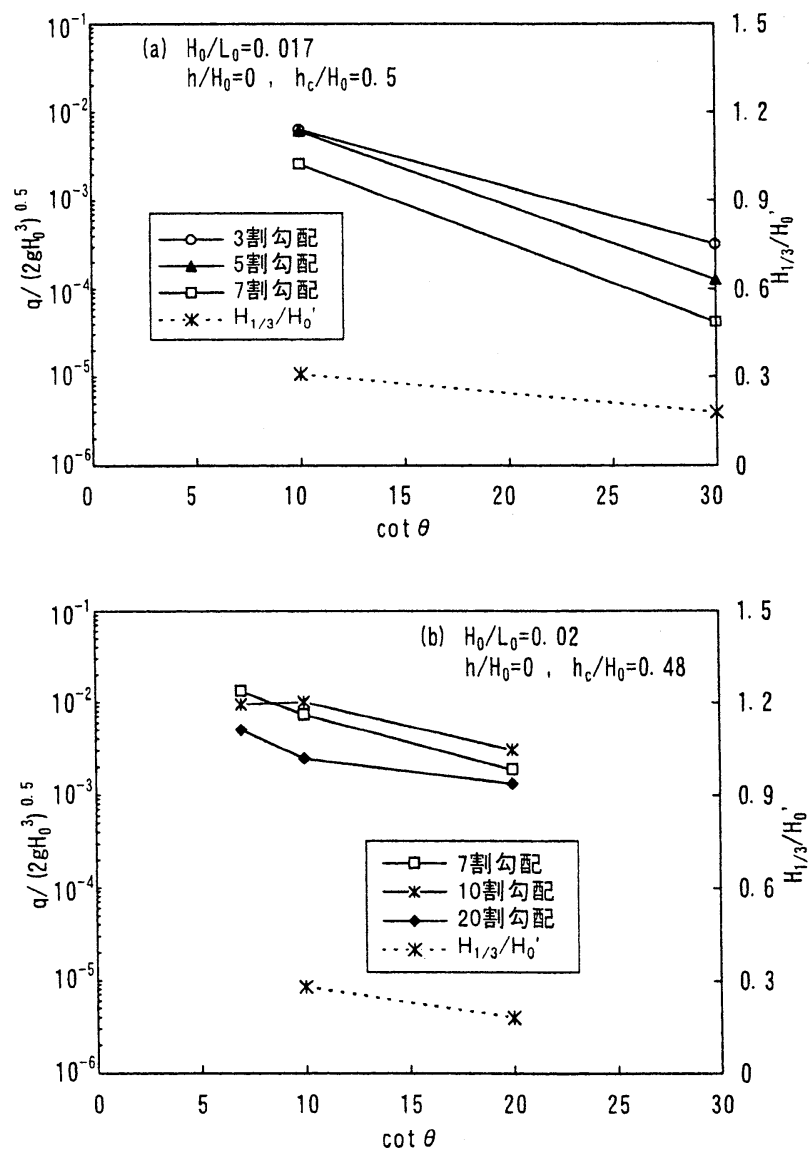

図-7 無次元越波流量と海底勾配との関係

\section{（4）のり面勾配の影響}

図一8には, 反射率 $\mathrm{K}_{\mathrm{r}}$, 越波率 $\mathrm{r}_{0}$ および無次元越波 流量 $\mathrm{q} / \sqrt{2 \mathrm{gH}_{0}{ }^{3}}$ とのり面勾配 $\cot \alpha$ との関係を示した. ここに, 図一8(a)は, 波形勾配 $\mathrm{H}_{0} / \mathrm{L}_{0}$ が $0.017 て ゙$ 相対護 岸天端高 $\mathrm{h}_{\mathrm{c}} / \mathrm{H}_{0}$ が 0.5 の場合, 図-8(b)は, 波形勾配 


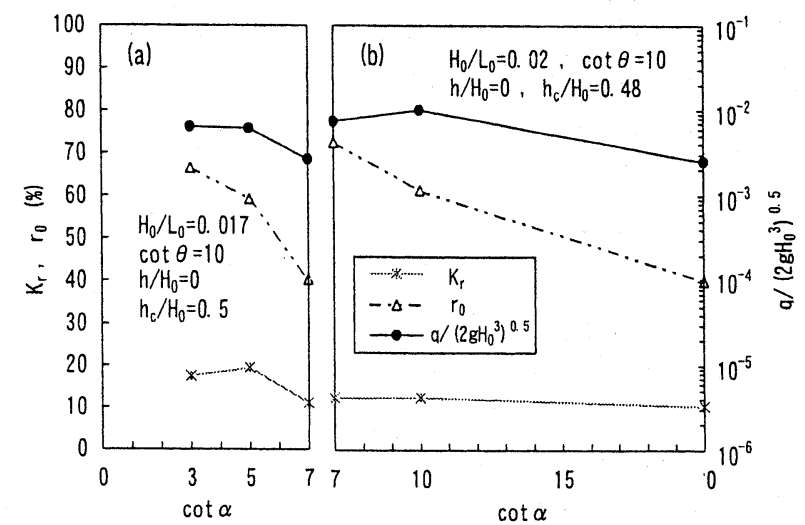

図-8 反射率, 越波率および無次元越波流量とのり面 勾配との関係

$\mathrm{H}_{0} / \mathrm{L}_{0}$ が $0.02 て ゙$ 相対護岸天端高 $\mathrm{h}_{\mathrm{c}} / \mathrm{H}_{0}$ が 0.48 の場合につ いてのものである.

これらの図によると， $\mathrm{K}_{\mathrm{r}}$ は，のり面勾配の違いに よる変動があまりみられず，特に，7割勾配護岸上 りも緩やかになると，その值はほぼ一定である， $\mathrm{r}_{0}$ については，のり面勾配が7割の場合に図ー8(a) と図 -8(b)の值には，かなりの差がみられるものの，の り面勾配が緩くなるとともに減少する傾向がみられ る. また，この傾向は，のり面が7割勾配よりも急 な護岸の $\mathrm{q} / \sqrt{2 \mathrm{gH}_{0}}$ についても同様にみられる.し かし，7割よりも緩いものについては，のり面勾配 の違いによる変動はあまりみられない。このように, 護岸ののり面勾配を7割程度まで緩くすれば，ある 程度の越波低減効果が期待できるが, 海底勾配との 組み合わせによっては，それ以上緩くしてもあまり その効果が発揮できない場合もある。

\section{4. 越波特性の時間的変動}

\section{（1）最大越波流量比および越波時の最大水位}

図ー9には，越波した波だけを対象とした場合の1 波ごとの最大越波流量比 $\mathrm{q}_{\max } / \mathrm{q}_{\mathrm{m}}$ および $\eta_{\max } / \mathrm{H}_{0}$ との り面勾配 $\cot \alpha$ との関係を示した.ここに， $\eta_{\max } / \mathrm{H}_{0}$ は, 護岸天端上における越波時の最大水位 $\eta_{\text {max }}$ を沖 波波高 $\mathrm{H}_{0}$ で除して無次元化したものである.

これによると, のり面が20割勾配の場合，いずれ の海底勾配においても， $\mathrm{q}_{\max } / \mathrm{q}_{\mathrm{m}}$ は3.4〜 4.4であり， 大差はみられない。一方, のり面が7割勾配の場合, 海底勾配が1/20のものと組み合わせると, $\mathrm{q}_{\max } / \mathrm{q}_{\mathrm{m}}$ は3 程度であるのに対して, 海底勾配も1/7のものと組 み合わせると, その值は6にも達する場合があり, 防災上きわめて危険である. また, 10 割の一様勾配 護岸では, $\mathrm{q}_{\max } / \mathrm{q}_{\mathrm{m}}$ が最も小さく, 2.6である.このよ うに, 海底勾配とのり面勾配の組み合わせの違いに よって, $\mathrm{q}_{\max } / \mathrm{q}_{\mathrm{m}}$ は大きく変動するため, 緩傾斜護岸 の計画に際しては, 細心の注意が必要である.

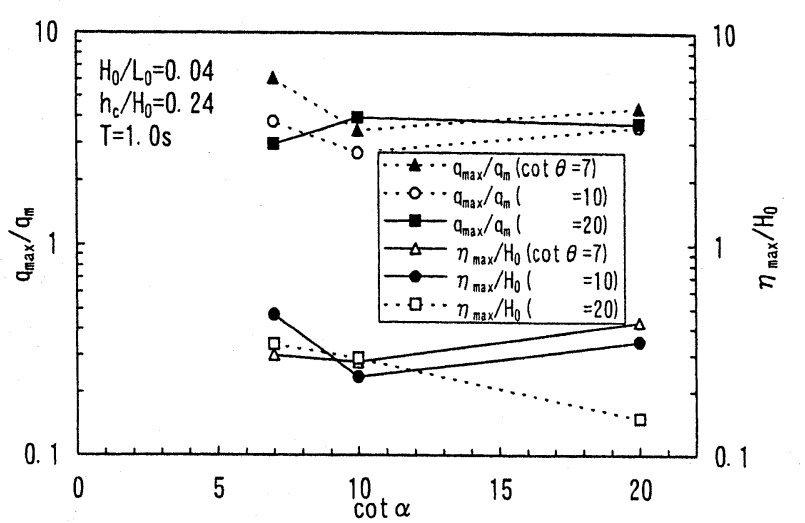

図-9 最大越波流量比および越波時の水位とのり面勾配 との関係

また，海底勾配が $1 / 7$ と $1 / 10$ の場合の $\mathrm{q}_{\max } / \mathrm{q}_{\mathrm{m}}$ は， $\eta_{\max } / \mathrm{H}_{0}$ とほぼ同様の傾向を示しながら変動してお り, 両者の間にはある程度の相関がみられる。

\section{（2）越波流量の出現頻度分布}

図ー10には，越波した波だけを対象とした場合に おける1波ごとの越波流量qの出現分布の一例を, 波 形勾配 $\mathrm{H}_{0} / \mathrm{L}_{0}$ が 0.04 で相対護岸天端高 $\mathrm{h}_{\mathrm{c}} / \mathrm{H}_{0}$ が 0.24 の場 合について示した.いずれの図も, 縦軸は 1 波ごと
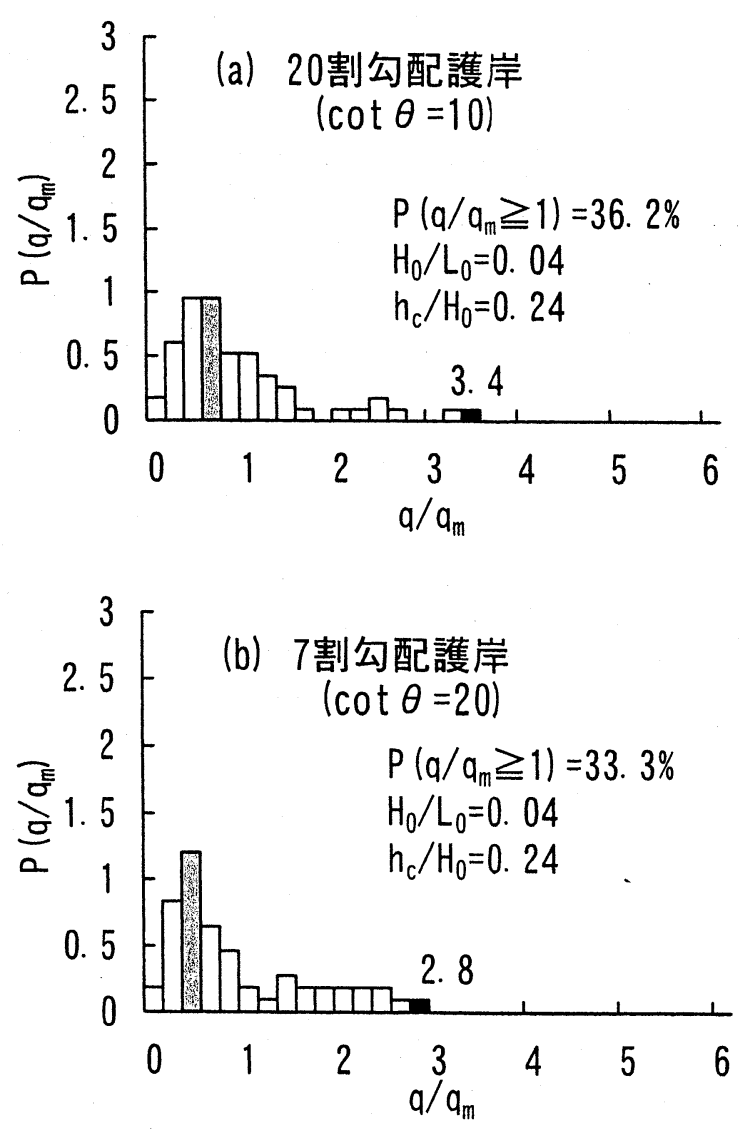

図-10 越波流量の出現頻度分布 （越波した波だけを対象とした場合） 
の越波流量 $\mathrm{q} の$ 出現確率 $\mathrm{P}\left(\mathrm{q} / \mathrm{q}_{\mathrm{m}}\right)$, 横軸は1波ごとの越 波流量と平均越波流量との比 $\mathrm{q} / \mathrm{q}_{\mathrm{m}}$ である7). なお, 図-10(a)は海底勾配が1/10，のり面勾配が20割の場 合，図 $-10(\mathrm{~b})$ は海底勾配が $1 / 20 ， の り$ 面勾配が7割 の場合のものである.

図一10(a)によると, $\mathrm{P}\left(\mathrm{q} / \mathrm{q}_{\mathrm{m}}\right)$ の最大値の出現する $\mathrm{q} / \mathrm{q}_{\mathrm{m}}$ は，0.6〜0.8であり，この值はのり面勾配が7割 の場合の $0.2 \sim 0.4 や 10$ 割のものの0.2 0.4よりも大き い. さらに, 平均越波流量よりも大きな越波流量の 出現確率 $\mathrm{P}\left(\mathrm{q} / \mathrm{q}_{\mathrm{m}} \geqq 1\right)$ は $36.2 \%$ でり, 他の護岸のもの と比べて小さいが, $\mathrm{q}_{\max } / \mathrm{q}_{\mathrm{m}}$ は3.4にもなる.このこと から, 平均越波流量だけで機能設計を行うことは, 背後地の条件によっては, 危険な場合が生じること もあり, 特に, のり面勾配が 20 割のような超緩傾斜 護岸に执いては, その機能設計に際して, 十分な注 意が必要である.

図ー10(b)によると, $\mathrm{P}\left(\mathrm{q} / \mathrm{q}_{\mathrm{m}} \geqq 1\right)$ は33.3\%で，この值 は、のり面勾配が緩やかなものよりも小さく, しか も， $\mathrm{q}_{\max } / \mathrm{q}_{\mathrm{m}}$ も2.8である.このようなことから，海底 勾配が $1 / 20$ のうにやや緩やかな場合には, のり面 が7割程度のものと組み合わせると, 短時間越波特 性の面からも, 非常に優れた越波防止機能が期待で きる.

\section{5. 結 語}

以上，緩傾斜護岸の越波防止機能の向上を図るた め, 緩傾斜護岸の越波現象に関わる無次元量を種々 変化させた一連の越波実験を行い，緩傾斜護岸の越 波特性に及ぼす諸要素の影響を検討してきた。その 結果，以下のようなことが明らかになった。

1）いずれの護岸についても，反射率 $\mathrm{K}_{\mathrm{r}} に は$ ，相対 護岸天端高 $\mathrm{h}_{\mathrm{c}} / \mathrm{H}_{0}$ の影響はほとんどみられず，のり先 水深・波高比 $\mathrm{h} / \mathrm{H}_{0}$ や海底勾配がその支配要因となる. すなわち， $\mathrm{K}_{\mathrm{r}}$ はh $/ \mathrm{H}_{0}$ が増大したり, 海底勾配が急に なるとともに增大し, 特に, 3割勾配護岸で $\mathrm{h} / \mathrm{H}_{0}$ が 0.71 の場合における $\mathrm{K}_{\mathrm{r}}$ は $40 \%$ 程度にもなる。

2) 越波率 $\mathrm{r}_{0}$ および $\mathrm{H}_{1 / 3} / \mathrm{H}_{0}$ ' と越波流量 $\mathrm{q} / \sqrt{2 \mathrm{gH}_{0}}{ }^{3}$ との 間には相関がみられる。すすなわち，これらは，越波 現象に関わる各々の無次元量の変化に伴い, ほぼ同 様の傾向を示しながら変化する。 また, 越波率 $\mathrm{r}_{0}$ や 越波流量 $\mathrm{q} / \sqrt{2 \mathrm{gH}_{0}}$ は, $\mathrm{h} / \mathrm{H}_{0}$ の増大や $\mathrm{h}_{\mathrm{c}} / \mathrm{H}_{0}$ の減少に 伴い増大し, 護岸ののり面勾配や海底公配が緩くな ると減少する場合が多い。特に，のり面勾配が5割 より緩い緩傾斜護岸の越波低減機能は優れている.

3) のり面勾配が急な3割勾配護岸では, 陸上部に設
置した場合に限って，その越波防止効果が期待でき る. また, 護岸ののり面勾配と海底勾配を同じにす ると，のり面勾配が緩いにもかかわらず，それが急 なものよりも $\mathrm{q} / \sqrt{2 \mathrm{gH}_{0}}$ は増大することがある。す なわち，海底勾配との組み合わせによっては，のり 面勾配が比較的急な緩傾斜護岸においても，その越 波防止機能を向上させることができる.

4) 最大越波流量比 $q_{\max } / q_{m}$ は, 海底勾配が1/7および 1/10の場合には, 10 割勾配護岸のものが最も小さく なり, その值は3程度である。.また, 平均越波流量 よりも大きなものの出現確率は, 20割勾配護岸が最 も小さいが, 最大越波流量比 $\mathrm{q}_{\max } / \mathrm{q}_{\mathrm{m}}$ は他のものに比 べて大きい。このため，20割勾配のような超緩傾斜 護岸の計画に際しては, 平均越波流量だけでなく, 短時問越波流量についても十分に考虑しなければな らない。

5） $1 / 20$ の傾斜海浜上に7割勾配護岸を設置した場合, $\mathrm{P}\left(\mathrm{q} / \mathrm{q}_{\mathrm{m}} \geqq 1\right)$ が最小值の $33.3 \%$ を示すとともに, 最大越 波流量比 $\mathrm{q}_{\max } / \mathrm{q}_{\mathrm{m}}$ も2.8になり, 短時間越波特性の面か らも非常に優れた越波防止機能を発揮する.

謝辞：本研究の実験や資料整理には，現在，関西大 学大学院の田中克彦, 矢作建設工業の野㠃裕史の両 君, また, 論文のまとめには関西大学大学院の片山 敦史君が大いに助力してくれたことを明記して謝意 を表する，なお，この研究には，平成14年度関西大 学学術研究助成基金を使用した.

\section{参考文献}

1) 井上雅夫: 親水性護岸における越波特性, 第29回水 工学に関する夏期研修会講義集，Bコース, pp.B-6-1 〜B-6-15, 1994.

2）玉田 崇・井上裕規・井上雅夫：緩傾斜護岸におけ る越波流量算定図の提案と時間的変動特性に関する 考察，海洋開発論文集，第17巻，pp.311３16，2001.

3）宇多高明：緩傾斜護岸に保わる様々な問題点の整理, 海洋開発論文集, 第15巻, pp.523 528, 1999.

4）豊島 修: 続 - 緩傾斜護岸Q\&A, 海岸, No.28, pp.51 60, 1988.

5）合田良実：浅海域における波浪の砕波変形，運輸省 港湾技術研究所報告, 第14巻, 第3号, pp.59〜106, 1975.

6）合田良実：䂥波指標の整理について, 土木学会論文 報告集, No.180, pp.39〜49, 1970.

7）井上雅夫・島田広昭・殿最浩司：不規則波における 越波量の出現分布特性, 海岸工学論文集, 第36巻, pp.618 622, 1989. 